\title{
Differing Wariness for Approaching Humans among Cormorant Migrants Advancing into Rural or Urban Habitats
}

\author{
Kei'ichiro Iguchi ${ }^{1}$, Hideki Tanaka ${ }^{2}$, Takushi Shinagawa ${ }^{2}$, Tetsuya Tsuruta $^{3}$, Takaharu Natsumeda ${ }^{4}$, Koji Konish $^{2} \&$ \\ Shin-ichiro $\mathrm{Abe}^{4}$ \\ ${ }^{1}$ Graduate School of Fishery Science and Environmental Studies, Nagasaki University, Nagasaki, Japan \\ ${ }^{2}$ Gunma Fisheries Experiment Station, Gunma, Japan \\ ${ }^{3}$ Department of Human Life and Environment, Faculty of Human Environment, Osaka Sangyo University, \\ Osaka, Japan \\ ${ }^{4}$ Department of Science Education, Faculty of Education, Ibaraki University, Ibaraki, Japan \\ Correspondence: Kei'ichiro Iguchi, Graduate School of Fishery Science and Environmental Studies, Nagasaki \\ University, 1-14 Bunkyo, Nagasaki 852-8521, Japan. E-mail: keyichi@nagasaki-u.ac.jp
}

Received: August 27, 2015 Accepted: September 17, 2015 Online Published: October 15, 2015

doi:10.5539/jas.v7n11p180 URL: http://dx.doi.org/10.5539/jas.v7n11p180

\begin{abstract}
The great cormorant (Phalacrocorax carbo hanedae) is one of the largest piscivorous water birds in Japan. It is in the phase of recovery from a long-term decline in the numbers, with its population drastically increasing throughout Japan. This potentially impacts cormorant's predation conflicts with inland fisheries. Recent cormorant migrants often appear to inhabit more urbanized areas although the species once preferred habitats remote from human activities. This novel dwelling preference remains unexplained. The present study aimed to understand the processes promoting their expansion, especially focusing on those that help acquire foraging success in urban habitats. Measurements on primary production in aquatic ecosystem did not detect superiority of urban habitats over rural ones. This indicates that exploitation of a habitat by cormorants is less explicable by the potential food richness. Our field survey revealed that more urbanized habitats provided more frequent contacts with pedestrians who were indifferent to wildlife, potentially allowing cormorants' habituation to humans. The degree of tolerance to human-associated disturbances in cormorants was measured using flight-initiation distance (FID) defined as a distance at which an individual animal moves away from an approaching human. Urban cormorants showed shorter FID than those in the rural habitats suggesting that reduced threshold of risk-avoidance against approaching humans could be implicated in the increase in foraging opportunities. Our results suggest that recent urban environments are selectively advantageous for cormorants as new habitats.
\end{abstract}

Keywords: urbanization, Phalacrocorax carbo hanedae, flight-initiation distance, human-associated disturbance, habituation

\section{Introduction}

Cormorants are large piscivorous water birds inhabiting coastal and inland waters globally (Cramp \& Simons, 1977). Many cormorant populations have undergone dramatic fluctuations in size over the past century (De Nie, 1995; Grémillet et al., 1995; Lindell et al., 1995; Hatch, 1995; Weseloh et al., 1995). The great cormorant (Phalacrocorax carbo hanedae), dwelling in Japan, had also experienced a decline, close to a population collapse in early 1970's but it rapidly recovered, thereafter, and spread over inland waters (Naruse et al., 1997). Cormorants that have advanced into this novel habitat certainly damage the native fish community, including commercially important fishes, often causing conflicts with humans, particularly associated with fishing activities (Kameda et al., 2003; Iguchi et al., 2008; Adkins et al., 2014; Shwiff et al., 2015). However, reasons for such explosive increases are complex and remain unclear.

Previous studies show that cormorants earlier preferred rural habitats, remote from human activity (Ishida et al., 2000). An experimental study using repellent visual stimuli demonstrated that contemporary cormorants retained their sensitivity to a human figure (Yamamoto et al., 2012), suggesting that contact with humans is still perceived as a threat by cormorants. Nonetheless, a large number of cormorants have established their novel habitats in the 
midst of cities, where encounters with humans are common (Fukuda et al., 2002; Natsumeda et al., 2015). The basis on which cormorants choose their habitat remains unexplained. Adaptive individuals should analyze their habitats to maximize the net gain (Kennedy \& Greer, 1988; Kumada et al., 2013). In terms of benefits from food supplies, urban habitats are not particularly superior to their rural counterparts. At the same time, the increase in the net gain in the urban population of cormorants can be achieved by the cost reduction during foraging. City environments inevitably have human-associated disturbances (e.g., pedestrians, dogs, and cats). However, different way of looking at the situation is that habituation to humans with frequent interactions may realize favorable conditions for cormorants in urban habitats (Knight et al., 1987).

Animals, when confronted with approaching threats, estimate the risk based on numerous factors such as body size, behavioral characters, social status, and physical conditions (Stankowich \& Blumstein, 2005; Cooper Jr., 2006; Rodriguez-Prieto et al., 2008). The distance at which an animal begins to flee from the approaching threat varies with the magnitude of the estimated risk (Bonenfant \& Kramer, 1996; Cooper Jr. \& Frederick, 2007). Flight-initiation distance (FID) is defined as the distance at which an individual animal moves away from an approaching human (Ydenberg \& Dill, 1986; Bonenfant \& Kramer, 1996). FID is employed as a measure of acclimation to human-associated disturbances in cormorants that are exposed to different levels of urbanization. Repeated exposure to humans is known to decrease FID in the wildlife (Lord et al., 2001; Miller et al., 2001; Ikuta \& Blumstein, 2003). We hypothesized that cormorants that are accustomed to urbanized areas have shorter FID than those accustomed to less urbanized areas. The information on cormorant management in urban habitats is quite limited (Taylor et al., 2011). This study aimed to understand the process promoting cormorant habitat expansion, especially focusing on those affecting the foraging success in urban habitats, by testing the above-mentioned hypothesis.

\section{Methods}

\subsection{Study Site}

Field investigations were conducted along four water courses running through Gunma Prefecture, Japan, on weekdays, from May through October, 2008. These streams are artificially stocked with Ayu (Plecoglossus altivelis), a commercially important fish in Japan, mainly for recreational fishing. The great cormorant had been very rare in this district because of the large distance of inland waters from the coastal area until immigration began in early 2000's (Fukuda et al., 2002). The Watarase Stream (WS; $36^{\circ} 30^{\prime} \mathrm{N}, 139^{\circ} 17^{\prime} \mathrm{E}$ ), Kasu Stream (KS; $36^{\circ} 21^{\prime} \mathrm{N}, 139^{\circ} 12^{\prime} \mathrm{E}$ ), Momonoki Stream (MS; $36^{\circ} 24^{\prime} \mathrm{N}, 139^{\circ} 06^{\prime} \mathrm{E}$ ), and Ino Stream (IS; $36^{\circ} 20^{\prime} \mathrm{N}, 139^{\circ} 02^{\prime} \mathrm{E}$ ), all of which are tributaries of the Tone River, the longest river in Japan, were selected on the basis of the habitat-type (Figure 1). The former two streams flow between farmland areas, which correspond to rural habitats; whereas, the latter two are located in city areas and are classified as urban habitats. The stream width at the study sites varied in the range 28-43, 9-13, 24-29, and 4-11 m in WS, KS, MS, and IS, respectively. Each study site had a car-free pathway on the bank for the convenience of resident people. The frequency of pedestrians denoted the relative riverine human activity. Simultaneous counts of walkers passing along the bank during morning hours between 07:30 and 09:30 a. m. were repeated three times at each study site. Different observations were made at the same point in each of the streams. 


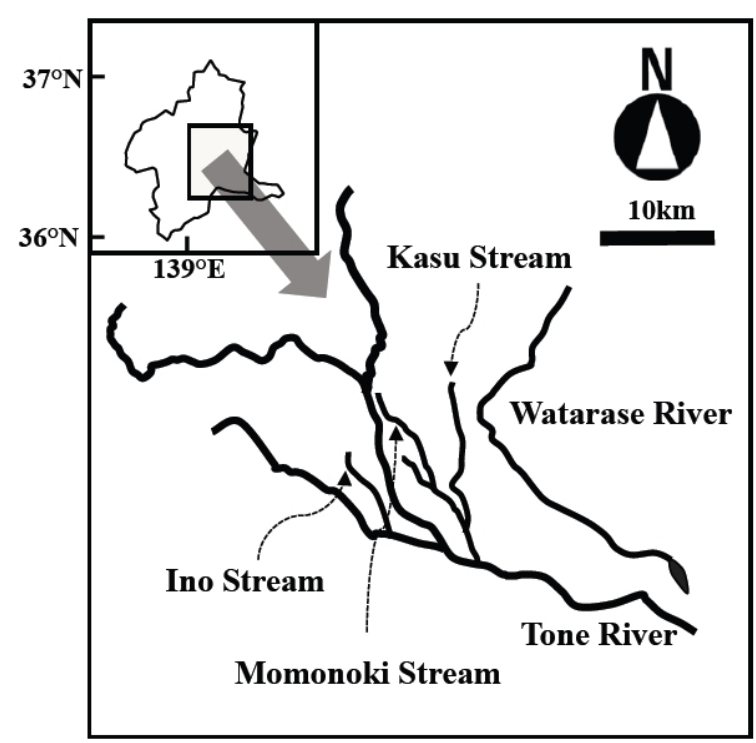

Figure 1. Map of study sites

\subsection{Primary Production}

Primary production around the study sites was determined from the growth rate of the algal community attached to stream-bed stones, using ash-free dry-mass (AFDM) and chlorophyll $a$ content estimation (Stevenson, 1990). Collection of algal samples was done simultaneously at each study site on days with fair weather. Cobbles and boulders selected randomly from the stream-bed $(n=10)$ were brushed inside a $5 \times 5$-cm quadrat to remove algae from the stone surface. The remaining substrates were kept in a 5-mm net cage anchored to the stream-bed to protect from grazers until the second collection of algal samples on the next day. The samples stored in a bottle were filtered through a pre-ashed glass fiber filter (Whatman $\mathrm{GF} / \mathrm{C}$, Whatman International Inc., Maidstone, UK). Portions of algal assemblages left on the fine mesh were dried at $80{ }^{\circ} \mathrm{C}$ for $24 \mathrm{~h}$, and then combusted at $600{ }^{\circ} \mathrm{C}$ for $24 \mathrm{~h}$. The difference in the weight of dry mass and residual ash was designated as AFDM. Another portion of the filtered algae was preserved at $-20{ }^{\circ} \mathrm{C}$, from which chlorophyll was extracted using $90 \%$ acetone for $24 \mathrm{~h}$ at $4{ }^{\circ} \mathrm{C}$. Spectrophotometric analysis was used to quantitate the chlorophyll $a$ content (Steinman \& Lamberti, 1996).

\subsection{Flight-Initiation Distance}

Collection of the behavioral data of birds was synchronized at each study site from sunrise to noon on different days. A pair of observers walked on the designated sections of 10.8, 4.7, 8.5, and $11.7 \mathrm{~km}$ along WS, KS, MS and IS, respectively. These sections contained a range of reaches, riffles, rapids, and pools, and water. When a cormorant was spotted, observers were careful not to disturb it by their presence. One of the observers then walked directly towards the bird at a constant pace of $0.5 \mathrm{~m} / \mathrm{s}$. Flight-initiation distance (FID) was recorded for cormorants that were accessible by foot. This distance was determined by a measuring tape or, occasionally, by a laser rangefinder (Laser $800 \mathrm{~S}$, Nikon, Tokyo, Japan). After recording the FID for a bird, the observers moved to another location so as not to bias the subsequent approaches to other birds. Quality of the foraging patches used by the birds was estimated, especially in MS and IS. Moreover, whenever possible, prey richness was assessed at each point where a cormorant was spotted. An electric fisher (Smith-Root, Vancouver, WA, USA) was used to efficiently collect fish at $300 \mathrm{~V}$ DC pulse from water column with depth less than $1 \mathrm{~m}$. Fish anesthetized with FA 100 (Takeda Chemical Industries, Tokyo, Japan) were classified, counted, and then re-released into the reach from where they were captured, following recovery from the anesthetic. Catch per unit effort (CPUE, standardized number of fish captured during 10 min of electrofishing) was employed as an indicator of prey richness.

\subsection{Data Analysis}

Variations observed in WS, KS, MS, and IS were presented graphically on box-plots, in which median, $25^{\text {th }}$, and $75^{\text {th }}$ percentiles, and largest and smallest values were displayed. The variance data obtained from these four sites were subjected to ANOVA to detect the differences among the sites. This was followed by post-hoc comparisons 
between pairs of sites using Games-Howell test (Games \& Howell, 1997). For detecting significant differences between two sites, the variance at the two sites was analyzed using Student's - $t$ - test. All statistical analyses were performed using the SPSS statistical package (SPSS Japan Inc., Tokyo, Japan).

\section{Results}

The number of morning pedestrians varied among the localities ranging between 3 and 258 people (Figure $2 ; F_{3,8}$ $=315.953, P<0.001$ ). More people used paths on the bank along MS and IS (MS vs. WS, $P=0.0032$; MS vs. $\mathrm{KS}, P=0.003$; IS vs. WS, $P=0.007$; IS vs. KS, $P=0.007)$, without paying attention to birds foraging in the water. AFDM was similar among the algal samples collected from different localities (Figure $3 ; F_{3,36}=1.242, P$ $=0.309$ ). Chlorophyll $a$ content also did not differ significantly between the localities (Figure $4 ; F_{3,36}=2.426, P$ $=0.081)$ although that of a sample obtained from MS showed slightly higher chlorophyll $a$ levels (MS vs. WS, $P$ $=0.001$; MS vs. IS. $P=0.001)$.

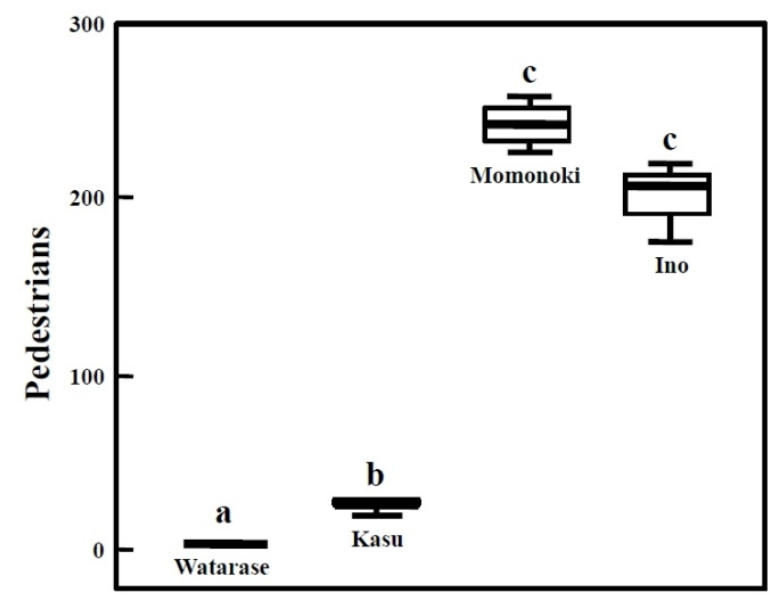

Water courses

Figure 2. Box-plotted frequency of pedestrians observed during morning hours between 7:30 and 9:30 at each locality. Different letters indicate significantly different main effects

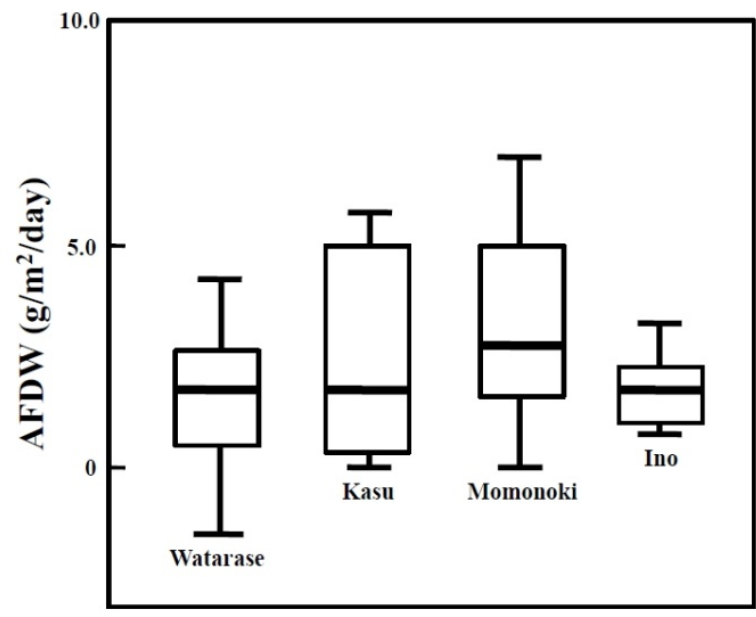

Water courses

Figure 3. Box-plotted ash free dry mass (AFDM) of algae attached to substrates at each locality 


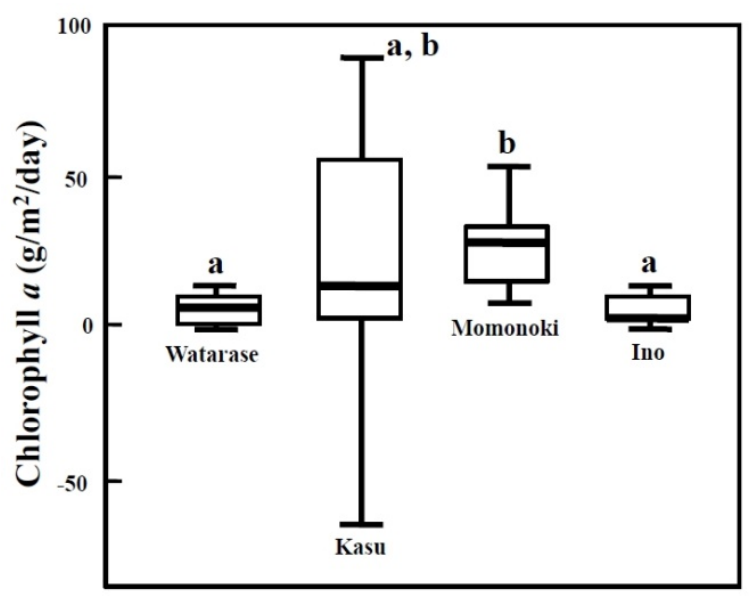

Water courses

Figure 4. Box-plotted content of Chlorophyll $a$ in attached algae at each locality. Different letters indicate significantly different main effects

FID varied among the localities (Figure $5 ; F_{3,39}=11.427, P<0.001$ ), with cormorants at WS and KS showing greater FID than those at MS and IS (WS vs. MS, $P=0.004$; WS vs. IS, $P=0.006$; KS vs. MS, $P=0.003$; KS vs. IS, $P=0.010)$. MS and IS had similar variations in CPUE for potential bait fishes $(t=-1.468, d f=11, P=0.165)$, as well as, in FID $(t=0.820, d f=11, P=0.429)$, indicating that these two localities were comparable. Log-transformed variables showed negative relationships between FID and CPUE (Figure 6; MS, $r=-0.758, n=$ $5, P=0.138$; IS, $r=-0.626, n=8, P=0.097$ ), although data on CPUE were insufficient for further analysis.

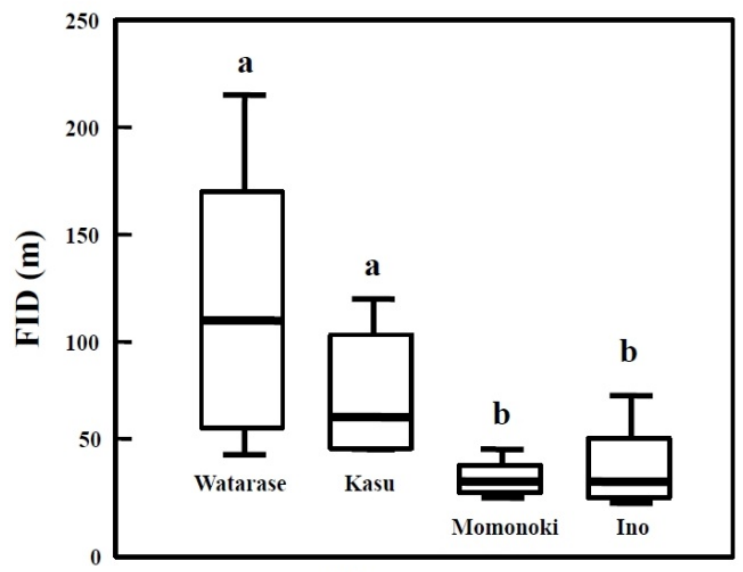

Water courses

Figure 5. Box-plotted flight-initiation distance (FID) at each locality. Different letters indicate significantly different main effects 

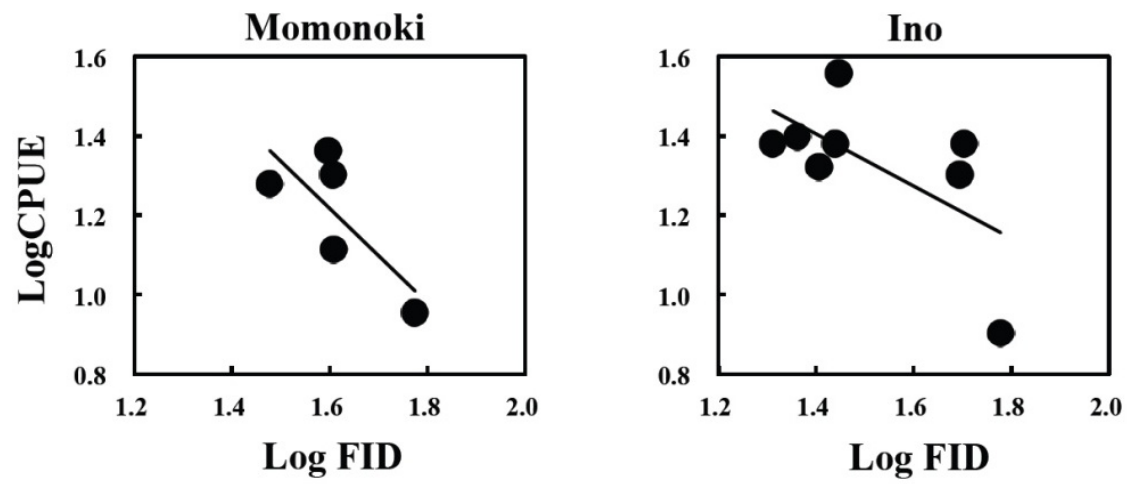

Figure 6. Relationship between log-transferred flight-initiation distance (FID) and log-transferred catch per unit effort (CPUE) for potential bait fishes in Momonoki and Ino Streams with regression lines

\section{Discussion}

The inland waters of Japan appear to be preferable for travelling cormorants in terms of food supply. This is probably due to the numerous dams and weirs constructed along the water courses that interrupt the upstream migration of Ayu (Plecoglossus altivelis) and, hence, intensive stocking is undertaken in the upper reaches to compensate for its use in recreational fishing (Pastene et al, 1991; Kubota et al., 2008). Hatchery-rearing practices give fish a common character to make an assemblage without spreading; consequently, they become an easy prey in the field (Tsukamoto \& Uchida, 1990). Therefore, inland waters where Ayu is stocked abundantly provide cormorants with a motive for foraging. Increased accessibility to foods due to stocking has been observed in the case of European cormorants that have moved into inland areas (Kennedy \& Greer, 1988).

Inland areas provide both rural and urban habitats. Cormorants in the past were known to inhabit rural areas (Ishida et al., 2000); whereas, the current cormorant populations are successful in establishing themselves in urban habitats, as shown in this study. The rationale of how cormorants choose their habitat remains unclear. In general, urbanization resists natural predators (Tomialojc, 1982), which results in lower perceived predation risk for the prey (Sorace, 2002). Reduced predation pressure can be beneficial to cormorants even though they might have practically no predators in the inland areas. Further, recreational and/or sports fishing have become popular among outdoor enthusiasts in Japan (Imamura \& Murakami, 2005) who prefer to fish in the suburbs rather than in the urbanized streams. Because anglers are a threat for cormorants, urban waters unfavorable for anglers can be regarded as safe zones for cormorants. Both AFDM and chlorophyll $a$ content, indices of primary production in an ecosystem, did not differ significantly between the urban and rural habitats. This implies that exploitation of these habitats by cormorants is less explicable by their potential food richness.

Remarkable difference between the two habitat-types was observed in the number of pedestrians who were unconcerned with water birds. Urbanization is generally accompanied by increased disturbances due to human activities that have adverse effects on avian abundance and their reproductive success (Gill et al., 1996; Lord et al., 1997). In the context of human-associated disturbances, streams running through the urbanized areas would deteriorate their suitability as habitats for water birds. However, urbanization sometimes promotes the abundance of certain species that have high tolerance to human activities (Valcarcel \& Fernández-Juricic, 2009). In a traditional fishing method in Japan, U-kai fishing, live cormorants are used to catch Ayu, in which a fisherman on a boat manipulates multiple lines with well-trained birds (Jouy, 1888; Hayama, 2002). Their capacity for learning seems to enable an easy habituation to humans. Our field tests proved that cormorants dwelling in more urbanized habitats had a shorter FID than those in the less urbanized habitats. This indicates that frequent encounters with ordinary commuters make cormorants alter their threshold of risk-avoidance involving humans. Indeed, at one time, when resident people harmed the cormorants in the course of collecting their droppings, the cormorants located their habitats away from villages and towns to avoid contact with humans (Ishida et al., 2000).

Reduced FID allows an extended period available for collecting food. Because increased foraging time enhances foraging success in cormorants (Morrison et al., 1978), there is a possibility of it contributing to the fitness of cormorants in the urban life. Cormorants that occurred in the two streams, MS and IS, in this study, returned to the same roost (Konishi, unpublished data), suggesting that the two habitats were used by a single group that shares a colony. Our survey detected the tendency that FIDs in urban habitats decreased with the increase in 
CPUE at the foraging site although sample sizes were not sufficient. Leaving a good patch requires costs in terms of abandonment of the remaining opportunity for feeding (Blumstein et al., 2003) while benefits are brought about by avoidance from the human-associated disturbance. Thus, the negative correlation between FID and CPUE is explicable by an optimizing process to maximize the difference between benefits and costs (Ydenberg \& Dill 1986; Bonenfant \& Kramer 1996). FID adjusted to by the urban cormorants is deemed to be a consequence of their adaptive response based on the risk assessment. In the background of achieving adaptation, people who do not pose a threat, provide a selective pressure. Newly acquired urban life is likely to contribute to cormorant's fitness.

\section{Acknowledgements}

We thank K. Suzuki, Y. Kanzawa, and N. Suzuki for collectiong the field data. Field research permits were issued by Gunma Prefecture. All the fish collections complied with the current laws of the country in which they were performed. Financial support for this study partly came from the Ministry of Agriculture, Forestry and Fisheries Japan.

\section{References}

Adkins, J. Y., Robby, D. D., Lyons, D. E., Curtot, K. N., Collis, K., Carter, H. R., ... Capitolo, P. J. (2014). Recent population size, trends, and limiting factors for the double-crested cormorant in western North America. $J$ Wildl Manage, 78, 1131-1142. http://dx.doi.org/10.1002/jwmg.737

Blumstein, D. T., Anthony, L. L., Harcourt, R., \& Ross, G. (2003). Testing a key assumption of wildlife buffer zones: is flight initiation distance a species-specific trait? Biol Conserv, 110, 97-100. http://dx.doi.org/10.1016/S0006-3207(02)00180-5

Bonenfant, M., \& Kramer, D. L. (1996). The influence of distance to burrow on flight initiation distance in the woodchuck, Marmota monax. Behav Ecol, 7, 299-303. http://dx.doi.org/10.1093/beheco/7.3.299

Cramps, S., \& Simmons, K. E. L. (1977). The birds of the Western Palaearctic (Vol. 1). Oxford University Press, Oxford, UK.

Cooper Jr., W. E. (2006). Dynamic risk assessment: prey rapidly adjust flight initiation distance to change in predator approach speed. Ethology, 112, 858-864. http://dx.doi.org/10.1111/j.1439-0310.2006.01240.x

Cooper Jr., W. E., \& Frederick, W. G. (2007). Optimal flight initiation distance. J Theor Biol, 244, 59-67. http://dx.doi.org/10.1016/j.jtbi.2006.07.011

De Nie, H. (1995). Changes in the inland fish populations in Europe in relation to the increase of the cormorant Phalacrocorax carbo sinensis. Ardea, 83, 115-122.

Fukuda, M., Narusue, M., \& Kato, N. (2002). Changes in the distribution and abundance of great cormorant Phalacrocorax carbo in Japan. Jpn J Ornithol, 51, 4-11. http://dx.doi.org/10.3838/jjo.51.4

Games, P. A., \& Howell, J. F. (1976). Pariwise multiple comparison procedures with unequal N's and/or variances: Monte Curlo study. $J$ Educ Behav Stat, 1, 113-125. http://dx.doi.org/10.3102/10769986001002113

Gill, J. A., Sutherland, W. J., \& Watkinson, A. R. (1996). A method to quantify the effects of human disturbance on animal populations. $J$ Appl Ecol, 33, 786-792. http://dx.doi.org/10.2307/2404948

Grémillet, D., Schmid, D., \& Culik, B. (1995). Energy-requirements of breeding great cormorants Phalacrocorax carbo sinensis. Mar Ecol Prog Ser, 121, 1-9. http://dx.doi.org/10.3354/meps121001

Hatch, J. J. (1995). Changing populations of double-crested cormorants. Colon Waterbirds, 18, 8-24. http://dx.doi.org/10.2307/1521520

Hayama, S. (2002). Policy for the management of the Great Cormorant in Japan. Jpn J Ornithol, 51, 56-61. http://dx.doi.org/10.3838/jjo.51.56

Iguchi, K., Tsuboi, J., Tsuruta, T., \& Kiryu, T. (2008). Foraging habits of great cormorant in relation to released ayu stocks as a food source. Aquacult Sci, 56, 415-422.

Ikuta, L. A., \& Blumstein, D. T. (2003). Do fences protect birds from human disturbance? Biol Conserv, 112: 447-452. http://dx.doi.org/10.1016/S0006-3207(02)00324-5

Imamura, K., \& Murakami, S. (2005). A study on uses of space in the Biwa Lake shore Park. J Jpn Inst Landscape Architect, 68, 799-802. http://dx.doi.org/10.5632/jila.68.799

Ishida, A., Matsuzawa, T., Kameda, K., \& Narusue, M. (2000). The population increase of the great cormorant 
Phalacrocorax carbo and its damaging effect on fisheries and trees in Japan - The present situation, the problems in each area and future measures. Strix, 18, 1-28.

Jouy, P. L. (1888). On cormorant fishing in Japan. Am Nat, 22, 1-3. http://dx.doi.org/10.1086/274626

Kameda, K., Ishida, A., \& Naruse, M. (2003). Population increase of great cormorant Pharacrocorax carbo hanedae in Japan: conflicts with fisheries and trees and future perspectives. Vogelwelt, 124, 27-33.

Kennedy, G. J. A., \& Greer, J. E. (1988). Predation by cormorants, Phalacrocorax carbo (L.), on the salmonid populations of an Irish river. Aquacul Res, 19, http://dx.doi.org/10.1111/j.1365-2109.1988.tb00419.x

Knight, R. L., Grout, D. J., \& Temple, S. A. (1987). Nest-defense behavior of the American Crow in urban and rural areas. Condor, 89, 175-177. http://dx.doi.org/10.2307/1368772

Kubota, H., Tezuka, K., \& Fukutomi, N. (2008). Discrimination of stock origins of ayu Plecoglossus altivelis caught by angling, using microsatellite DNA markers and evaluation of stocking effectiveness. Nippon Suisan Gakkaishi, 74, 1052-1059. http://dx.doi.org/10.2331/suisan.74.1052

Kumada, N., Arima, T., Tsuboi, J., Ashizawa, A., \& Fujioka, M. (2013). The multi-scale aggregative response of cormorants to the mass stocking of fish in rivers. Fish Res, 137, 81-87. http://dx.doi.org/10.1016/j.fishres.2012.09.005

Lindell, L., Mellin, M., Musil, P., Przybysz, J., \& Zimmerman, H. (1995). Status and population development of breeding cormorants Phalacrocorax carbo sinensis of central-European flyway. Ardea, 83, 81-92.

Lord, A., Waas, J. R., \& Innes, J. (1997). Effects of human activity on the behavior of Northern New Zealand dotterel Charadrius obscurus aquilonius chicks. Biol Conserv, 82, 15-20. http://dx.doi.org/10.1016/S0006-3207(97)00013-X

Lord, A., Waas, J. R., Innes, J., Whittingham, M. J., (2001). Effects of human approach to nests of northern New Zealand dotterel. Biological Conservation, 82, 15-20. http://dx.doi.org/10.1016/S0006-3207(97)00013-X

Miller, S. G., Knight, R. L., \& Miller, C. K. (2001). Wildlife responses to pedestrians and dogs. Wildl Soc Bull, 29, 124-132.

Morrison, M. L., Slack, R. D., \& Shanley Jr, E. (1978). Age and foraging ability relationships of Olivaceous Cormorants. Willson Bull, 90, 414-422.

Natsumeda, T., Sakano, H., Tsuruta, T., Kameda, K., \& Iguchi, K. (2015). Immigration of the common cormorant Phalacrocorax carbo hakonedae into inland areas of the northern part of Nagano Prefecture, eastern Japan, inferred from stable isotopes of carbon, nitrogen and sulphur. Fish Sci, 81, 131-137. http://dx.doi.org/10.1007/s12562-014-0823-X

Pastene, L. A., Numachi, K., \& Tsukamoto, K. (1991). Examination of reproductive success of transplanted stocks in an amphidromous fish, Plecoglossus altivelis (Temmink et Schlegel) using mitochondrial DNA and isozyme markers. J Fish Biol, 39(Supplement A), 93-100. http://dx.doi.org/10.1111/j.1095-8649.1991.tb05072.x

Rodriguez-Prieto, I., Fernánde-Juricic, E., Martin, J., \& Regis, Y. (2008). To run or to fly: low cost versus low risk escape strategy in blackbirds. Behaviour, 145, 1125-1138. http://dx.doi.org/10.1163/156853908784474489

Shwiff, S. A., Kirkpatrick, K. N., \& Shwiff, S. S. (2015). Modeling the economic impacts of double-crested cormorant damage to a recreational fishery. Human-Wildlife Interactions, 9, 36-47.

Sorace, A. (2002). High density of bird and pest species in urban habitats and the role of predator abundance. Ornis Fennica, 79, 60-71.

Stankowich, T., \& Blumstein, D. T. (2005). Fear in animals: a meta-analysis and review of risk assessment. Proc R Soc B: Biology, 272, 2627-2634. http://dx.doi.org/10.1098/rspb.2005.3251

Steinman, A. D., \& Lamberti, G. A. (1996). Biomass and pigments of benthic algae. In F. R. Hauer, \& G. S. Lamberti (Eds.), Methods in Stream Ecology (pp. 295-313). Academic Press, San Diego, USA.

Stevenson, R. J. (1990). Benthic algal community dynamics in a stream during and after a spate. J North Am Benthol Soc, 9, 277-288. http://dx.doi.org/10.2307/1467591

Taylor, B., Andrews, D., \& Fraser, G. S. (2011). Double-crested cormorants and urban wilderness: conflicts and management. Urban Ecosyst, 14, 377-394. http://dx.doi.org/10.1007/s11252-011-0165-8 
Tomialojc, L. (1982). Synurbanization of birds and prey-predators relations. In: M. Luniak, \& B. Pisarski (Eds.), Animals in Urban Environments (pp. 131-137). Ossolineum, Wroclaw, Poland.

Tsukamoto, K., \& Uchida, K. (1990). Spacing and jumping behavior of the ayu Plecoglossus altivelis. Nippon Suisan Gakkaishi, 56, 1383-1392. http://dx.doi.org/10.2331/suisan.56.1383

Valcarcel, A., \& Fernández-Juricic, E. (2009). Antipredator strategy of house finches: are urban habitats safe spots from predators even when humans are around. Behav Ecol Sociobiol, 63, 673-685. http://dx.doi.org/10.1007/s00265-008-0701-6

Weseloh, D. V., Ewin, P. J., Struger, J., Mineau, P., Bishop, C. A., Postupalsky, S., \& Ludwig, J. P. (1995). Double-crested cormorants of the Great Lakes: changes in population size, breeding distribution and reproductive output between 1913 and 1991. Colon Waterbirds, 18, 48-59. http://dx.doi.org/10.2307/1521523

Yamamoto, M., Kuwayama, H., Suzuki, S., Takahashi, A., \& Kato, A. (2012). Evaluations of effective psychological stress on Great Cormorants using heart rate as an index of psychological stress. Jpn J Ornithol, 61, 29-37. http://dx.doi.org/10.3838/jjo.61.29

Ydenberg, R. C., \& Dill, L. M. (1986). The economics of fleeing from predators. Adv Study Behav, 16, 229-249. http://dx.doi.org/10.1016/S0065-3454(08)60192-8

\section{Copyrights}

Copyright for this article is retained by the author(s), with first publication rights granted to the journal.

This is an open-access article distributed under the terms and conditions of the Creative Commons Attribution license (http://creativecommons.org/licenses/by/3.0/). 